\title{
Pharmacological Evaluation of
}

\section{Aldehydic-Pyrrolidinedione Against HCT-I 16, MDA-MB23 I, NIH/3T3, MCF-7 Cancer Cell Lines, Antioxidant and Enzyme Inhibition Studies}

This article was published in the following Dove Press journal:

Drug Design, Development and Therapy

\begin{abstract}
Ashfaq Ahmad'
Farhat Ullah'

Abdul Sadiq'

Muhammad Ayaz (D)

Haroon Rahim (D) ${ }^{2}$

Umer Rashid ${ }^{3}$

Sajjad Ahmad'

Muhammad Saeed Jan (1D'

Riaz Ullah ${ }^{4}$

Abdelaaty A Shahat (D) ${ }^{4,5}$

Hafiz Majid Mahmood ${ }^{6}$

'Department of Pharmacy, University of Malakand, Chakdara, Dir (L), KP (Khyber Pakhtunkhwa) I8000, Pakistan;

${ }^{2}$ Department of Pharmacy, Sarhad University of Science \& Information Technology, Peshawar, KP (Khyber Pakhtunkhwa), Pakistan; ${ }^{3}$ Department of Chemistry, COMSATS University Islamabad, Abbottabad Campus, Abbottabad 22060, KP (Khyber Pakhtunkhwa), Pakistan; ${ }^{4}$ Department of Pharmacognosy (MAPPRC), College of Pharmacy, King Saud University Riyadh, Riyadh, Saudi Arabia; ${ }^{5}$ Phytochemistry Department, National Research Centre, Giza, Egypt; ${ }^{6}$ Department of Pharmacology, College of Pharmacy, King Saud University, Riyadh I I45I, Saudi Arabia
\end{abstract}

Correspondence: Haroon Rahim; Abdul Sadiq

Department of Pharmacy, Sarhad University of Science and Information Technology Peshawar, Peshawar, Khyber Pakhtunkhwa, Pakistan; Department of

Pharmacy, University of Malakand Khyber Pakhtunkhwa, Chakdara 18800, Pakistan Tel +92-332946I642; +92-30I-2297I02 Email hrahimpk@gmail.com, sadiquom@yahoo.com
Purpose: The current work was designed to synthesize a bioactive derivative of succinimide and evaluate it for anti-Alzheimer, anticancer and anti-diabetic potentials.

Methods: The compound was synthesized by Michael addition of butyraldehyde with $N$-phenylmaleimide. The synthesized compound was screened for biological potentials including anti-cholinesterase, in-vitro anti-diabetic, antioxidant and anthelmintic potentials. The anti-cholinesterase potential was evaluated against acetylcholinesterase (AChE) and butyrylcholinesterase (BChE), anti-diabetic potential against $\alpha$-glucosidase, antioxidant potential against ABTS, DPPH and $\mathrm{H}_{2} \mathrm{O}_{2}$ and anthelmintic potential against Perethima posthuma and Ascaridia galli respectively.

Results: The compound demonstrated significant AChE and BChE inhibition i.e., 71.34 \pm 1.92 and $73.42 \pm 1.92$ at the concentration of $1000 \mu \mathrm{g} / \mathrm{mL}$ respectively. Other dilutions exhibited concentration-dependent inhibitory activity against both enzymes. In the MTT assay, the newly synthesized compound was found active against all of the cell lines viz, HCT-116, MDA-MB231, NIH/3T3 and MCF-7 and the highest cytotoxicity potential was observed against the colon cancer cell line (HCT-116) with an $\mathrm{IC}_{50}$ value of $78 \mu \mathrm{g} / \mathrm{mL}$ exhibiting its highest potential. Moreover, the compound exhibited prominent $\alpha$-glucosidase inhibitory potentials $(79.86 \pm 2.54 \%$ at $1000 \mu \mathrm{g} / \mathrm{mL})$ with $\mathrm{IC}_{50}$ value of $156.23 \mu \mathrm{g} / \mathrm{mL}$. Further, our test compound exhibited considerable scavenging activity against DPPH, ABTS and $\mathrm{H}_{2} \mathrm{O}_{2}$ free radicals with percent inhibitions of $75.84 \pm 1.58,72.85 \pm 1.17$ and $54.82 \pm 1.82$ and $\mathrm{IC}_{50}$ values of $84.36,139.74$ and $752.21 \mu \mathrm{g} / \mathrm{mL}$ respectively. Our test sample exhibited significant anthelmintic potentials. It demonstrated significant paralysis and death of the test worms in an unbelievably short time in comparison with albendazole.

Conclusion: Going into the detail of all observations, it may be deduced that the newly synthesized succinimide derivative could be an important drug candidate against neurodegenerative disorders like Alzheimer's disease, cancer, diabetes mellitus and worms. Further detailed studies in animal models are required for in-vivo analysis of the compound.

Keywords: Succinimide, Alzheimer's disease, MTT, oxidative stress, diabetes, helminthiasis

\section{Introduction}

The world has long been combating various types of health crises in different ways. It has been evidenced that the world has overcome the majority of health challenges but still there is dire need for continuous research activities to facilitate life with good health. ${ }^{1}$ Pharmacotherapy is playing a vital role in the management of various 
types of health anomalies. The drug has been provided by nature in the form of natural products or in the form of raw materials from which we synthesize a variety of synthetic drugs. ${ }^{2-4}$ Some of the raw materials include a special type of scaffold which is proved to be very effective after some modification, by formation of derivatives via addition of different functional groups. The synthetic derivatives have been proved to provide some extraordinary drug candidates to the market to treat various disease conditions. Some diseases are still there which target specific groups of people and are not curable although they could be managed with the help of medicinal products. For instance, Alzheimer's disease (AD) is one of the diseases which target the old age population and a variety of drug candidates are used for the management of the symptoms related to $\mathrm{AD} .^{5-8} \mathrm{AD}$ is prevalent in those countries which have a large number of old age population, which comprise developed countries of the world. ${ }^{9}$ Similarly, the underdeveloped nations of the world are facing different malnutrition problems due to the absence of proper food and proper hygienic measures. ${ }^{10-12}$ Inappropriate hygienic conditions also lead to the infestation of individuals by different types of worms. ${ }^{13-15}$ Worm infestation has been reported to be the cause of a large number of gastrointestinal, liver and blood problems. ${ }^{16}$ In the same way, free radicals have been reported to be the cause of different challenging diseases including cancer. ${ }^{17-20}$ Among all of the challenging diseases, the most lethal and horrible is obviously cancer, which could only be cured if properly diagnosed in the first two stages but still the drugs exploited against the cancer are associated with a plethora of adverse effects. Moreover, one of the disease conditions which are prevalent around the globe is diabetes mellitus. This disease has also been managed successfully with the help of different types of drugs. ${ }^{21,22}$

Valuable scaffolds of the drug type molecules have been synthesized and explored by organic and medicinal chemists. $^{23-26}$ As stated earlier, synthetic drugs have added a lot to the management and therapy of different types of diseases. One of the scaffolds which have been showing promising results in the formation of bioactive derivatives is the succinimide. Different succinimide derivatives have been synthesized and demonstrated with significant biological activities. ${ }^{27-29}$ Based on the clinical importance of succinimide and the need of the day, the current research project has been designed to synthesize a bioactive derivative of succinimide and evaluate its biological potentials against cholinesterases, cancer cell lines, $\alpha$-glucosidase, worms and free radicals.

\section{Materials and Methods Chemicals}

For synthesis of the aldehyde derivative of succinimide, all chemicals, reagents and solvents which were used in this research work include $N$-phenylmaleimide (CAS No. 941-69-5), butyraldehyde (CAS No. 123-72-8), potassium hydroxide (CAS No. 1310-58-3), dichloromethane (DCM) (CAS No. 75-09-2), ethyl acetate (EtOAc) (CAS No. 141-786), $n$-hexane (CAS No. 110-54-3), methanol (CAS No. 67-56-1) and dimethyl sulfoxide (DMSO) (CAS No. 67-685) purchased from Sigma-Aldrich GmbH USA. The reaction progress was observed using analytical chromatographic plates (TLC Silica gel $60 \mathrm{~F}_{254}$ ) made in Germany purchased from the native market in Peshawar, KPK, Pakistan.

For in-vitro inhibition of cholinesterase, the chemicals including AChE from electric eel (type-VI-S, CAS No. 9000-81-1) and BChE from equine serum lyophilized (CAS No. 9001-08-5) were purchased from Sigma-Aldrich GmbH USA. Acetylthiocholine iodide (CAS No. 1866-15-5) and butyrylthiocholine iodide (CAS No. 2494-56-6) which stand in as enzyme substrates were purchased from authorized Sigma-Aldrich Switzerland and Sigma-Aldrich UK respectively. The indicator substance for cholinesterase inhibition assay, 5,5-dithio-bis-nitrobenzoic acid (DTNB) (CAS No. 69-78-3), was purchased from Sigma-Aldrich Germany. Galanthamine hydrobromide Lycoris Sp. (CAS No. 1953-044), acting as a standard drug, was purchased from SigmaAldrich France.

The intended assay for free radical scavenging, the chemicals and reagents, with DPPH (CAS No. 1898-66-4, Sigma Aldrich Chemie GmbH USA), ABTS (CAS No. 30931-67-0, Sigma Aldrich USA), $\mathrm{K}_{2} \mathrm{~S}_{2} \mathrm{O}_{4}$ (Riedel-de Haen Germany) and gallic acid (CAS No. 149-91-7, GmbH USA), and hydrogen peroxide (CAS No. 7722-84-1) were acquired from Merck Co. (Germany). The cell lines were purchased from ATCC (http://www.lgcstandards-atcc.org/) and the studies were conducted in Dr. Panjwani Centre for Molecular Medicine and Drug Research, ICCBS, University of Karachi, Pakistan.

\section{Synthesis of 2-(2,5-Dioxo-I- Phenylpyrrolidin-3-YI)Butanal}

Michael addition was used for $\mathrm{C}-\mathrm{C}$ bond formation between the Michael acceptor and donor. ${ }^{30}$ To promote the reaction, 
L-isoleucine $(0.1 \mathrm{~mol} \%, 13.117 \mathrm{mg})$ and potassium hydroxide $(0.1 \mathrm{~mol} \%, 5.6 \mathrm{mg})$ were added to a small reaction vessel containing $1.0 \mathrm{~mL}$ of DCM (dichloromethane). Then, butyraldehyde $(2.0 \mathrm{mmol}, 0.359 \mu \mathrm{L})$ and $1.0 \mathrm{mmol}(173.17 \mathrm{mg})$ of $\mathrm{N}$-phenylmaleimide were added at room temperature as shown in Scheme 1. Subsequently, TLCs (EtOAc/ $n$-hexane 20:80) were taken. After $10 \mathrm{~h}$, the reaction was fully completed. Thereafter, the reaction was diluted with $15 \mathrm{~mL}$ of water. Extraction was done with $15 \mathrm{~mL}$ of dichloromethane in triplicate. Organic layers combined were dried with $\mathrm{Na}_{2} \mathrm{SO}_{4}$, filtered and finally concentrated via rotary evaporator. The resultant mixture was further purified using column chromatography. ${ }^{29}$

\section{Anticancer Studies MTT Assay}

The synthesized compound was investigated against cancer cell lines viz, NIH/3T3, HCT-116, MDA-MB-231, MCF-7 and a normal cell line i.e., WI-38 at various concentrations via 96-well flat microplate reader at a wavelength of $570 \mathrm{~nm}$ following the standard MTT assay. ${ }^{31}$ Briefly, the selected cell lines were cultured in DMEM medium, supplemented with $10 \%$ of FBS along with selected antibiotics i.e., $100 \mu \mathrm{g} / \mathrm{mL}$ of streptomycin and penicillin $(100 \mathrm{IU} / \mathrm{mL})$ in flasks and incubated at $37{ }^{\circ} \mathrm{C}$ containing $5 \%$ of $\mathrm{CO}_{2}$. Cell cultures were prepared having an initial density of $6 \times 10^{4}$ cells $/ \mathrm{mL}$ with $80 \%$ confluence and $200 \mu \mathrm{L} /$ well of media was transferred into 96-well plates, which were put in an incubator. The medium was discarded from each plate after overnight incubation and the same amount of fresh medium with different concentrations (31.25-1000 ppm) of test samples was added into each well. After $48 \mathrm{~h}, 200 \mu \mathrm{L}$ MTT $(0.5 \mathrm{mg} / \mathrm{mL})$ was transferred into each well and put in an incubator for $4 \mathrm{~h}$. Afterward, DMSO $(100 \mu \mathrm{L})$ was transferred into each microplate well. The extent of reduction of MTT to formazan within the cells was calculated by measuring the absorption value at $570 \mathrm{~nm}$, through a microplate reader (Spectra Max plus; Molecular Devices, CA, USA). The $\mathrm{IC}_{50}$ value was recorded for the samples causing $50 \%$ cytotoxicity for all of the cell lines.

\section{Anti-Cholinesterase Studies}

Acetylcholinesterase (AChE) and butyrylcholinesterase (BChE) inhibitory assays were performed following our previously reported spectrophotometric method. ${ }^{6}$ In this assay, both enzymes act on their respective substrates to form an intermediate compound called 5-thio-2-nitrobenzoate anion. This anion forms a complex with another reagent called DTNB and result in the yellow color compound formation which is quantified on UV.

\section{Preparation of Solutions}

Our test sample was dissolved in previously prepared 0.1 $\mathrm{M}$ phosphate buffer to form solutions ranging from 62.5 to $1000 \mu \mathrm{g} / \mathrm{mL}$. For the adjustment of the solution $\mathrm{pH}$, potassium hydroxide was used. For the preparation of AChE solution $518 \mathrm{U} / \mathrm{mg}$ and for BChE solution 7-16 U/mg was dissolved in phosphate buffer to form $0.03 \mathrm{U} / \mathrm{mL}$ and 0.01 $\mathrm{U} / \mathrm{mL}$ solutions respectively. ${ }^{27}$ Likewise, DTNB solutions $(0.0002273 \mathrm{M})$, acetyl thiocholine iodide (ATchI) and butyryl thiocholine iodide (BTchI) $0.0005 \mathrm{M}$ solutions were made using double-distilled water. All solutions were maintained in Eppendorf tubes in the refrigerator. Standard drug (galanthamine) solutions were prepared in methanol at the same concentrations.

\section{Spectroscopic Analysis}

In the spectroscopic analysis, solutions of the enzymes (5 $\mu \mathrm{L})$ and $205 \mu \mathrm{L}$ of test compound were sequentially added to the cuvette. Thereafter, $5 \mu \mathrm{L}$ of DTNB solution was added to the mixture in the cuvette. The mixture of three reagents was sustained for $15 \mathrm{~min}$ at $30{ }^{\circ} \mathrm{C}$ using a water

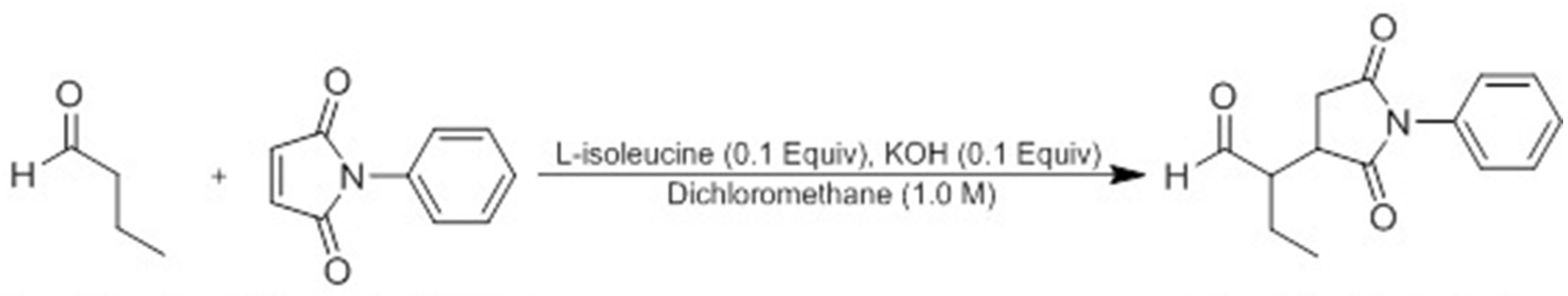

Butyraldehyde N-phenylmaleimide

Succinimide derivative

( $10 \mathrm{~h}, 85 \%$ yield)

Scheme I Michael addition of butyraldehyde to $\mathrm{N}$-phenylmaleimide. 
bath. Finally, $5 \mu \mathrm{L}$ of substrate solution was added to the reaction mixture. Absorbance was recorded via UV spectrophotometer at $412 \mathrm{~nm}$. A solution of the standard drug (galanthamine $10 \mu \mathrm{g} / \mathrm{mL}$ ) worked as the control drug whereas all solutions except the test compound were considered the negative control. UV absorbance values beside the reaction time were recorded for $4 \mathrm{~min}$ at $30{ }^{\circ} \mathrm{C}$. All assays were performed three times and inhibitory values for enzymes were obtained as follows:

$$
\begin{gathered}
\mathrm{V}=\Delta \mathrm{Abs} / \Delta \mathrm{t} \\
\% \text { enzyme inhibition }=100-\% \text { enzyme activity } \\
\% \text { enzyme activity }=\mathrm{V} / \mathrm{V}_{\max } \times 100
\end{gathered}
$$

where Vmax is activity of the enzyme in the complete absence of inhibitor agent.

\section{$\alpha$-Glucosidase Inhibition Studies}

The anti- $\alpha$-glucosidase potential of the synthesized compound was carried out with the help of a chromogenic assay. ${ }^{32,33}$ For such assay, $\alpha$-glucosidase solution was made having composition of $0.5 \mathrm{unit} / \mathrm{mL}$ and $20 \mu \mathrm{L}$ of prepared solution was mixed with $120 \mu \mathrm{L}$ of phosphate buffer ( $\mathrm{pH}$ 6.9). For the substrate, $p$-nitrophenyl- $\alpha$-D-glucopyranoside solution $(5 \mathrm{mM})$ was prepared in the same buffer. Briefly, $10 \mu \mathrm{L}$ of test sample having various concentrations $(31.25-1000 \mu \mathrm{g} / \mathrm{mL})$ was added to them in a test tube and kept back for $15 \mathrm{~min}$ at $37^{\circ} \mathrm{C}$. After incubation, $20 \mu \mathrm{L}$ of already prepared substrate solution was added to all of the samples and incubated for a further $15 \mathrm{~min}$. To terminate the reaction, sodium carbonate solution $(0.2 \mathrm{M})$ having a volume of $80 \mu \mathrm{L}$ was transferred to all tubes. Absorption at $405 \mathrm{~nm}$ was recorded for each sample. The reaction mixture with the test sample served as the control while acarbose served as the positive control. The $\%$ enzyme inhibitory potential was determined as follows:

\section{Antioxidant Studies \\ DPPH Radical Scavenging Assay}

The standard procedure was followed for the anti-radicals properties of the sample against DPPH free radicals. ${ }^{34}$ The stock solutions of synthesized compound were made in different dilutions $(62.50-1000 \mu \mathrm{g} / \mathrm{mL})$. To start the assay, $0.1 \mathrm{~mL}$ from each dilution of our synthesized compound was transferred to $3.0 \mathrm{~mL}$ of already prepared DPPH solution in methanol. The mixture was incubated for $30 \mathrm{~min}$ and absorbance values were recorded for all groups of samples at $517 \mathrm{~nm}$ via UV spectrophotometer. The \% scavenging effect of samples was calculated using the formula: $\left[\left(A_{0}-A_{1}\right) / A_{0}\right] \times 100$. Here,
$A_{0}$ is control group absorbance and $A_{1}$ represents our test compound absorbance.

\section{ABTS Anti-Radicals Study}

The ABTS anti-radicals assay was used following our previously reported procedures. ${ }^{35,36}$ In brief, various solutions including $\mathrm{K}_{2} \mathrm{~S}_{2} \mathrm{O}_{4}$ and ABTS $(7 \mathrm{mM})$ were prepared and combined. The mixture was incubated $\left(25^{\circ} \mathrm{C}\right)$ in a dark place for about $12-16 \mathrm{~h}$ to generate sufficient ABTS radicals. The resultant ABTS solution was diluted using previously prepared $0.01 \mathrm{M}$ phosphate buffer $(\mathrm{pH}$ 7.4) and the absorbance of the solution was adjusted to an absorbance value of 0.70 at $734 \mathrm{~nm}$.

Later, $300 \mu \mathrm{L}$ of our compound solution was mixed with $3.0 \mathrm{~mL}$ of ABTS radicals solution in an UV cuvette and the decrease in the absorbance was recorded. Like the DPPH assay, ascorbic acid again acted as the reference drug. Anti-radicals potentials were calculated as:

\section{$\mathrm{H}_{2} \mathrm{O}_{2}$ Anti-Radicals Study}

To assess further the anti-radicals potentials of our synthesized compound, an $\mathrm{H}_{2} \mathrm{O}_{2}$ assay was performed. ${ }^{37}$ A 2 $\mathrm{mM} \mathrm{H} \mathrm{H}_{2} \mathrm{O}_{2}$ solution prepared in $50 \mathrm{mM}$ phosphate buffer ( $\mathrm{pH}$ 7.4) was mixed with the previously prepared solution $(0.1 \mathrm{~mL})$ of test samples of various concentrations. UV absorbance was recorded at $230 \mathrm{~nm}$ against the blank after 10 min and the $\mathrm{H}_{2} \mathrm{O}_{2}$ scavenging effect was calculated as:

\section{Anthelmintic Studies}

Anthelmintic potentials of our test compound were evaluated against Pheretima posthuma and Ascaridia galli at concentrations of $10-40 \mathrm{mg} / \mathrm{mL} .{ }^{14,38}$ Due to both physiological and anatomical similarity with human intestinal roundworm Ascaris lumbricoides, P. posthuma were selected for investigation. The selected $P$. posthuma were collected on searching a muddy soil of Swabi, KPK, Pakistan, having average length of about 7-9 cm. A. galli were collected from the intestine of domestic chickens. Previously prepared different concentrations of the test compound (10 mg, $20 \mathrm{mg}$ and $40 \mathrm{mg}$ ) in distilled water and Tween 80 by making a suspension of them, $25 \mathrm{~mL}$ of each, were transferred into sterilized Petri dishes $(150 \times 15 \mathrm{~mm})$. An aqueous solution of albendazole was also prepared in the same concentration. From each solution, $25 \mathrm{~mL}$ was transferred to a Petri dish followed by six worms into each Petri dish with the help of forceps. Paralysis and death times were observed in hot water at $50{ }^{\circ} \mathrm{C}$. 


\section{Results}

\section{Chemistry}

The compound 2-(2,5-dioxo-1-phenylpyrrolidin-3-yl)butanal was synthesized in a single-step reaction and a shorter time of $10 \mathrm{~h}$ at room temperature. The isolated yield of the compound was $85 \%$. The $\mathrm{Rf}$ value of the synthesized compound was 0.46 . The ${ }^{1} \mathrm{H}$ NMR and ${ }^{13} \mathrm{C}$ NMR spectra are shown in Figures 1 and 2 respectively. ${ }^{1} \mathrm{H}$ NMR (400 $\mathrm{MHz}, \mathrm{CDCl}_{3}$ ) (ppm): $1.14(\mathrm{t}, J=7.50 \mathrm{~Hz}, 3 \mathrm{H}), 1.67-1.76$ (m, 1H), 1.92-2.02 (m, 1H), 2.51 (dd, $J=18.42,5.11 \mathrm{~Hz}$, $1 \mathrm{H}), 2.92-3.05(\mathrm{~m}, 2 \mathrm{H}), 3.29-3.41(\mathrm{~m}, 1 \mathrm{H}), 7.26-7.38(\mathrm{~m}$, $5 \mathrm{H}), 9.76(\mathrm{~s}, 1 \mathrm{H}) .{ }^{13} \mathrm{C}$ NMR $\left(100 \mathrm{MHz}, \mathrm{CDCl}_{3}\right)(\mathrm{ppm})$ : 12.72, 19.93, 31.98, 39.01, 53.48, 127.94, 128.63, 128.72, $128.78,135.72,175.37,177.47$ and 202.92 .

\section{Biological Studies \\ Results of MTT Assay}

The results of the cytotoxicity assay against various types of cell lines have been provided in Figure 3. As is obvious from Figure 3, the highest cytotoxicity has been shown by the test compound against HCT-116, while the lowest cytotoxicity potential has been exhibited against MDAMB-231. We can see from the results that at the highest concentration i.e., at $1000 \mathrm{ppm}$ the results of the test compound against almost all of the cell lines are comparable with the standard drug i.e., doxorubicin. The $\mathrm{IC}_{50}$ values exhibited by the test compound against HCT-116, MDA-MB-231, NIH/3T3 and MCF-7 were 78, 231, 181 and $277 \mu \mathrm{g} / \mathrm{mL}$ respectively. The test sample has also been screened against the normal cell line i.e., WI-38 to figure out cytotoxicity and it revealed that at $1000 \mathrm{ppm}$ the percent cytotoxicity was recorded as $16 \%$ and the $\mathrm{IC}_{50}$ value was calculated to be more than $3000 \mathrm{ppm}$ of the test compound. So, it has been proved to be safe to a considerable extent for the normal cells. It has been revealed that the test compound was potentially active against all of the cell lines.

\section{Anti-Cholinesterase Study}

The results of anti-cholinesterase activity of the test compound and the positive control are summarized in
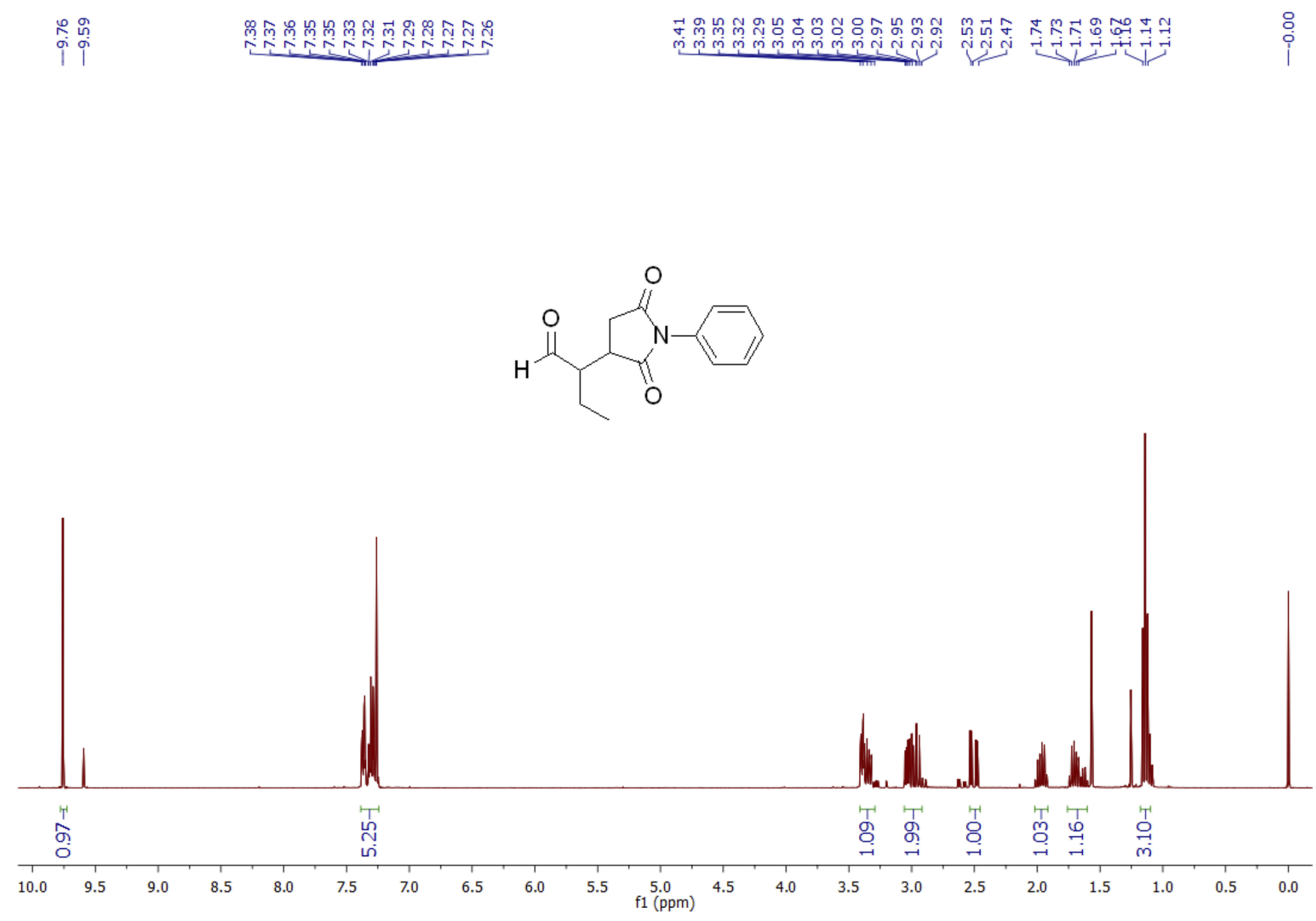

Figure I 'H NMR spectrum of 2-(2,5-dioxo-I-phenylpyrrolidin-3-yl)butanal. 


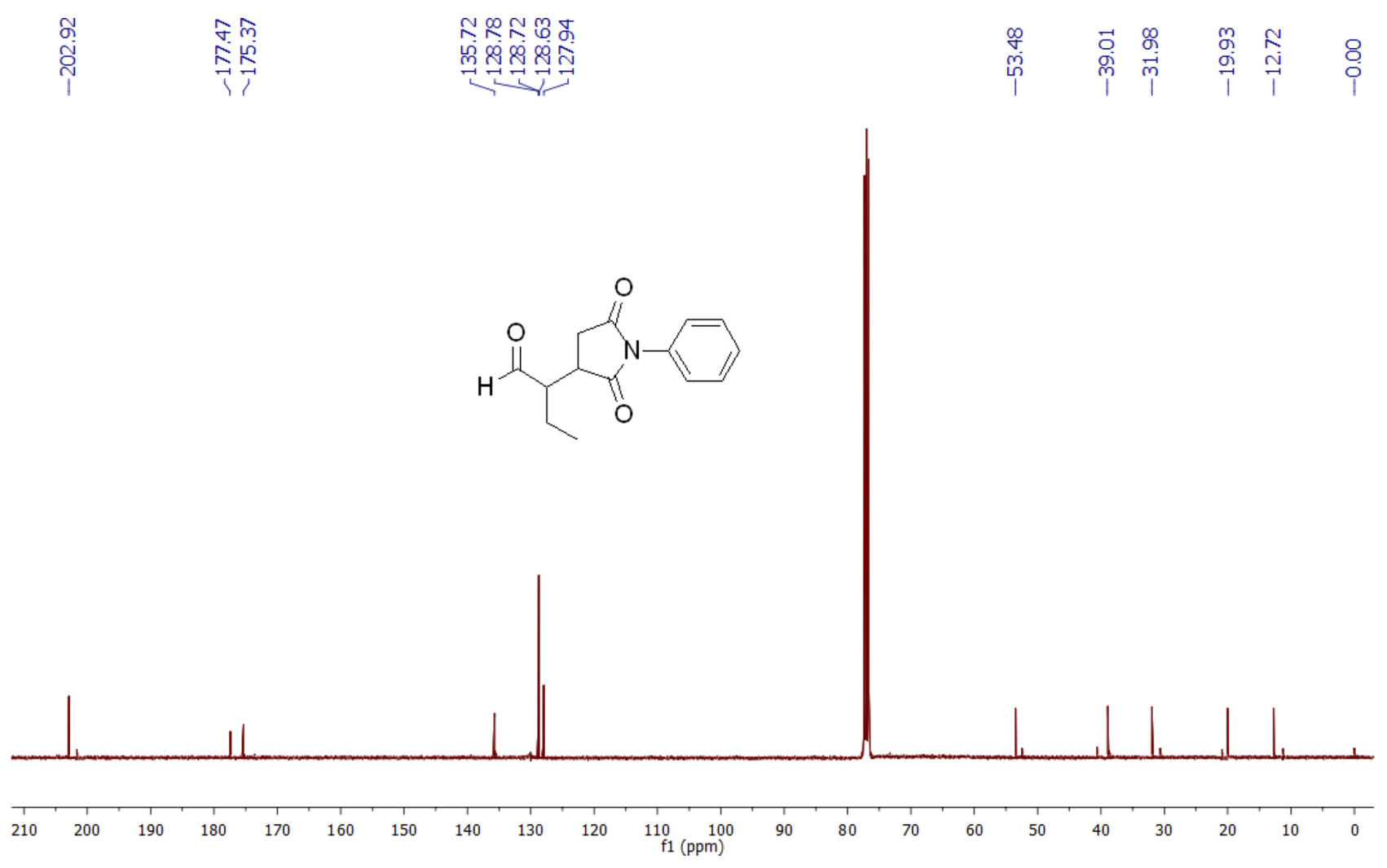

Figure $2{ }^{13} \mathrm{C}$ NMR spectrum of 2-(2,5-dioxo-I-phenylpyrrolidin-3-yl)butanal.

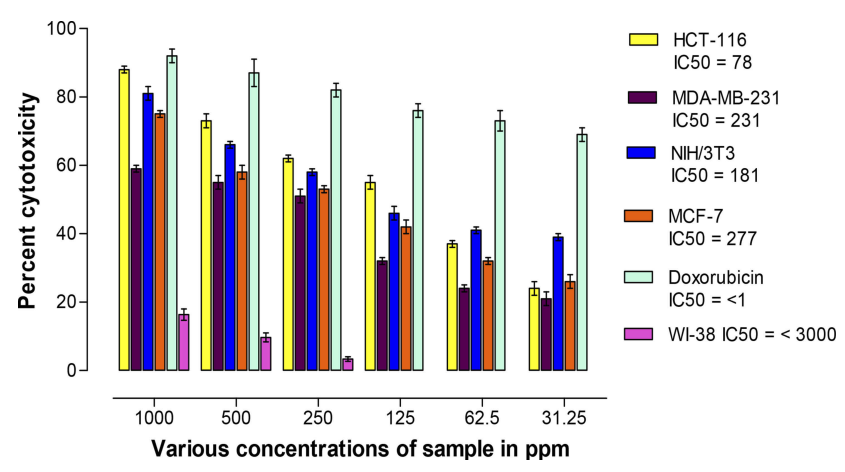

Figure 3 Percent cytotoxicity potential of test compound against various cell lines.

Table 1. 2-(2,5-Dioxo-1-phenylpyrrolidin-3-yl)butanal showed prominent anti-cholinesterase potential against both AChE and BChE. The \%anti-AChE and BChE potentials exhibited by the test compound were very comparable with the standard drug. The $\mathrm{IC}_{50}$ values of the test compound against $\mathrm{AChE}$ and $\mathrm{BChE}$ were calculated to be 103.6 and $132.3 \mu \mathrm{g} / \mathrm{mL}$, while the positive control showed the $\mathrm{IC}_{50}$ values of $9.8 \mu \mathrm{g} / \mathrm{mL}$ against $\mathrm{AChE}$ and $7.1 \mu \mathrm{g} / \mathrm{mL}$ against $\mathrm{BChE}$. This shows the effectiveness of newly synthesized succinimide derivative against Alzheimer's disease.

\section{$\alpha$-Glucosidase Inhibition Study}

The results of the $\alpha$-glucosidase inhibitory assay have been summarized in Table 2 . The percent inhibitory potential of the sample has been recorded to be nearly comparable with the standard drug i.e., acarbose. Our sample and positive control showed the percent inhibition of 79.9 and $86.7 \%$ respectively at $1 \mathrm{mg} / \mathrm{mL}$ while at the lowest concentration i.e., at the concentration of $31.25 \mu \mathrm{g} / \mathrm{mL}$, the test compound and positive control exhibited 18.7 and $59.7 \% \alpha$-glucosidase inhibition. The $\mathrm{IC}_{50}$ values for the compound and positive control were observed to be 162.6 $\mu \mathrm{g} / \mathrm{mL}$ and $<1 \mu \mathrm{g} / \mathrm{mL}$ respectively.

\section{Antioxidant Studies on ABTS, DPPH and $\mathrm{H}_{2} \mathrm{O}_{2}$}

The antioxidant potential of 2-(2,5-dioxo-1-phenylpyrrolidin-3-yl)butanal along with the positive control has been summarized in Table 3 . The test compound showed nearly comparable free radicals scavenging potential against all three types of free radicals. Against ABTS the compound exhibited the $\mathrm{IC}_{50}$ value of $84.36 \mu \mathrm{g} / \mathrm{mL}$, while the positive control showed $18.04 \mu \mathrm{g} / \mathrm{mL}$ against ABTS. Similarly, against DPPH the compound demonstrated an 
Table I Results of Acetylcholinesterase and Butyrylcholinesterase Inhibitory Potentials of 2-(2,5-Dioxo-I-Phenylpyrrolidin-3-YI) Butanal

\begin{tabular}{|c|c|c|c|c|c|}
\hline \multirow[t]{2}{*}{ Compound } & \multirow{2}{*}{$\begin{array}{l}\text { Concentration } \\
(\mu \mathrm{g} / \mathrm{mL})\end{array}$} & \multicolumn{2}{|c|}{ Acetylcholinesterase (AChE) } & \multicolumn{2}{|c|}{ Butyrylcholinesterase (BChE) } \\
\hline & & $\begin{array}{l}\text { Percent Inhibition } \\
\text { (Mean } \pm \text { SEM) }\end{array}$ & $\begin{array}{l}I_{50} \\
(\mu g / m L)\end{array}$ & $\begin{array}{l}\text { Percent Inhibition } \\
\text { (Mean } \pm \text { SEM) }\end{array}$ & $\begin{array}{l}\mathrm{IC}_{50} \\
(\mu \mathrm{g} / \mathrm{mL})\end{array}$ \\
\hline $\begin{array}{l}\text { 2-(2,5-Dioxo-I-phenylpyrrolidin-3-yl) } \\
\text { butanal }\end{array}$ & $\begin{array}{l}1000 \\
500 \\
250 \\
125 \\
62.5\end{array}$ & $\begin{array}{l}71.3 \pm 1.9 * * * \\
65.4 \pm 2.2 * * * \\
61.2 \pm 1.8 * * * \\
55.9 \pm 1.1 * * * \\
39.6 \pm 1.7 * * *\end{array}$ & $\begin{array}{l}103.6 \\
\pm 4.4\end{array}$ & $\begin{array}{l}73.4 \pm 1.9 * * * \\
64.3 \pm 0.3^{* * *} \\
52.7 \pm 1.7 * * * \\
49.3 \pm 1.3^{* * *} \\
36.9 \pm 1.9 * * *\end{array}$ & $\begin{array}{l}132.3 \\
\pm 7.5\end{array}$ \\
\hline Galanthamine & $\begin{array}{l}1000 \\
500 \\
250 \\
125 \\
62.5\end{array}$ & $\begin{array}{l}93.6 \pm 1.1 \\
85.4 \pm 0.2 \\
77.9 \pm 2.3 \\
71.9 \pm 1.5 \\
68.1 \pm 0.5\end{array}$ & $9.8 \pm 2.2$ & $\begin{array}{l}95.0 \pm 0.0 \\
89.4 \pm 0.5 \\
82.8 \pm 1.5 \\
78.6 \pm 1.7 \\
71.4 \pm 0.9\end{array}$ & $7.1 \pm 1.9$ \\
\hline
\end{tabular}

Notes: Values significantly different in comparison with galanthamine. $* * * P<0.001$.

Table 2 Percent $\boldsymbol{\alpha}$-Glycosidase Inhibitory Potential of 2-(2,5-Dioxo-I-Phenylpyrrolidin-3-YI)Butanal

\begin{tabular}{|c|c|c|c|c|c|c|c|}
\hline Samples & $3 \mathrm{I} .25 \mu \mathrm{g} / \mathrm{mL}$ & $62.5 \mu \mathrm{g} / \mathrm{mL}$ & $125 \mu g / m L$ & $250 \mu \mathrm{g} / \mathrm{mL}$ & $500 \mu \mathrm{g} / \mathrm{mL}$ & $1000 \mu \mathrm{g} / \mathrm{mL}$ & $\mathrm{IC}_{50} \mathrm{\mu g} / \mathrm{mL}$ \\
\hline Test compound & $18.7 \pm 2.6 * * *$ & $28.7 \pm 1.9 * * *$ & $47.4 \pm 2.4^{* * *}$ & $58.6 \pm 3.2^{* * * *}$ & $72.3 \pm 1.5 * *$ & $79.9 \pm 2.5^{*}$ & $162.6 \pm 7.4$ \\
\hline Acarbose & $59.7 \pm 1.7$ & $67.3 \pm 2.8$ & $71.7 \pm 1.7$ & $74.4 \pm 2.3$ & $81.7 \pm 2.6$ & $86.7 \pm 2.6$ & $<1$ \\
\hline
\end{tabular}

Notes: $* * * P<0.001, * * P<0.01, * P<0.05$

Table 3 Antioxidant Activity Result of 2-(2,5-Dioxo-I-Phenylpyrrolidin-3-YI)Butanal

\begin{tabular}{|c|c|c|c|c|c|c|c|}
\hline \multirow[t]{2}{*}{ S. No. } & \multirow{2}{*}{$\begin{array}{l}\text { Concentration } \\
(\mu \mathrm{g} / \mathrm{mL})\end{array}$} & \multicolumn{2}{|l|}{ ABTS } & \multicolumn{2}{|l|}{ DPPH } & \multicolumn{2}{|l|}{$\mathbf{H}_{\mathbf{2}} \mathbf{O}_{\mathbf{2}}$} \\
\hline & & $\begin{array}{l}\text { \% Inhibition } \\
\text { (Mean士SEM) }\end{array}$ & $\begin{array}{l}I_{50} \text { value } \\
(\mu \mathrm{g} / \mathrm{mL})\end{array}$ & $\begin{array}{l}\text { \% Inhibition } \\
\text { (Mean士SEM) }\end{array}$ & $\begin{array}{l}I_{50} \text { value } \\
(\mu \mathrm{g} / \mathrm{mL})\end{array}$ & $\begin{array}{l}\text { \% Inhibition } \\
\text { (Mean士SEM) }\end{array}$ & $\begin{array}{l}\text { IC }_{50} \text { value } \\
(\mu \mathrm{g} / \mathrm{mL})\end{array}$ \\
\hline $\begin{array}{l}\text { 2-(2,5-Dioxo-I- } \\
\text { phenylpyrrolidin-3-yl) } \\
\text { butanal }\end{array}$ & $\begin{array}{l}1000 \\
500 \\
250 \\
125 \\
62.5\end{array}$ & $\begin{array}{l}75.84 \pm 1.58 * \\
68.35 \pm 1.96 * * * \\
61.28 \pm 0.84 * * * \\
57.22 \pm 1.63 * * * \\
48.08 \pm 2.19 * * *\end{array}$ & 84.36 & $\begin{array}{l}72.85 \pm 1.17^{*} \\
71.36 \pm 1.92^{*} \\
61.41 \pm 2.36^{* * *} \\
49.01 \pm 1.28^{* * *} \\
33.32 \pm 2.04^{* * *}\end{array}$ & 139.74 & $\begin{array}{l}54.82 \pm 1.82 * * * \\
46.08 \pm 1.36 * * * \\
39.92 \pm 2.08 * * * \\
31.58 \pm 1.40 * * * \\
26.08 \pm 2.66 * * *\end{array}$ & 752.21 \\
\hline Ascorbic acid & $\begin{array}{l}1000 \\
500 \\
250 \\
125 \\
62.5\end{array}$ & $\begin{array}{l}81.85 \pm 0.18 \\
76.59 \pm 0.30 \\
69.75 \pm 0.14 \\
64.47 \pm 0.49 \\
59.12 \pm 0.34\end{array}$ & 18.04 & $\begin{array}{l}83.53 \pm 0.20 \\
78.62 \pm 0.17 \\
73.42 \pm 0.11 \\
66.20 \pm 0.15 \\
61.35 \pm 0.18\end{array}$ & 11.39 & $\begin{array}{l}78.00 \pm 1.15 \\
74.67 \pm 0.67 \\
68.85 \pm 1.85 \\
61.33 \pm 1.33 \\
56.67 \pm 1.67\end{array}$ & 29.73 \\
\hline
\end{tabular}

Notes: $* * * P<0.001, * P<0.05$.

$\mathrm{IC}_{50}$ value of $139.74 \mu \mathrm{g} / \mathrm{mL}$ and the positive control was observed with an $\mathrm{IC}_{50}$ value of $11.39 \mu \mathrm{g} / \mathrm{mL}$. Moreover, against the third free radical, the scavenging potential was observed to be moderate in comparison to the positive control. The $\mathrm{IC}_{50}$ values of $752.21 \mu \mathrm{g} / \mathrm{mL}$ for the test compound and 29.73 for the positive control against $\mathrm{H}_{2} \mathrm{O}_{2}$ show that against the $\mathrm{H}_{2} \mathrm{O}_{2}$ free radical, the compound is moderately active.

\section{Anthelmintic Studies}

The anthelmintic activity of our test sample has shown considerable wormicidal activity. The paralysis time and death time of our sample against both test worms i.e., $P$. posthuma and A. galli have been recorded to be lower than those of the positive control (albendazole). Against $P$. posthuma the paralysis time and death time observed at highest concentrations i.e., $40 \mathrm{mg} / \mathrm{mL}$ were 2.48 and 14.71 
Table 4 Anthelmintic Activity of 2-(2,5-Dioxo-I-Phenylpyrrolidin-3-YI)Butanal

\begin{tabular}{|l|l|l|l|l|l|}
\hline \multirow{2}{*}{$\begin{array}{l}\text { Samples/ } \\
\text { Groups }\end{array}$} & Concentration $(\mathbf{m g} / \mathrm{mL})$ & \multicolumn{2}{|l|}{ Pheretima posthuma } & \multicolumn{2}{l|}{ Ascaridia galli } \\
\cline { 3 - 6 } & & Paralysis Time (Min) & Death Time (Min) & Paralysis Time (Min) & Death Time (Min) \\
\hline \multirow{2}{*}{ Compound } & 10 & $06.67 \pm 1.08$ & $23.67 \pm 1.52$ & $06.54 \pm 1.67$ & $18.42 \pm 1.70$ \\
& 20 & $05.68 \pm 0.34$ & $19.23 \pm 2.56$ & $04.82 \pm 1.38$ & $11.36 \pm 1.94$ \\
& 40 & $02.48 \pm 1.62$ & $14.71 \pm 1.73$ & $02.19 \pm 0.96$ & $09.39 \pm 1.48$ \\
\hline \multirow{2}{*}{ Alb } & 10 & $09.08 \pm 1.56$ & $48.70 \pm 2.06$ & $11.26 \pm 2.81$ & $36.32 \pm 1.36$ \\
& 20 & $07.24 \pm 1.38$ & $39.33 \pm 1.54$ & $09.45 \pm 1.63$ & $32.56 \pm 1.93$ \\
& 40 & $04.67 \pm 0.57$ & $28.92 \pm 2.68$ & $07.18 \pm 1.74$ & $25.68 \pm 3.62$ \\
\hline
\end{tabular}

Note: Compound: 2-(2,5-dioxo-I-phenylpyrrolidin-3-yl)butanal.

Abbreviation: Alb, Albendazole.

min while for the positive control the paralysis time and death time were observed to be 4.67 and $28.92 \mathrm{~min}$, which shows the significance of the test compound versus the positive control. Similarly, against $A$. galli, the compound has shown extraordinary significance over the standard drug as shown in Table 4.

\section{Discussion}

The results of the current investigational studies reveal that our test sample could be one of the prominent bioactive derivatives of succinimide. AChE and $\mathrm{BChE}$ have been targeted to evaluate its potential role in the Alzheimer's disease (AD). Patients with AD show a very low concentration of acetylcholine $(\mathrm{ACh})$ at neuronal synapses throughout the nervous system. The amount of ACh could be increased by inhibiting the enzyme responsible for the breakdown of ACh i.e., AChE. Anticholinesterase drugs are available on the market which are used for the management of $\mathrm{AD}$ as there is no ultimate cure for $\mathrm{AD} .{ }^{39} \mathrm{AD}$ is also associated with the degeneration of neurons and the degeneration of neurons has been associated with the increased oxidative stress which in turn is associated with an increased amount of free radicals in the body. So scavenging the free radicals and decreasing the oxidative stress in the body could in turn decrease the chances of neuronal degeneration and hence decrease the chances of neurodegenerative disorders including $\mathrm{AD} .^{34,40,41}$ In the current study we have got a significant inhibitor of free radicals and $\mathrm{AChE}$ as obvious from the results. In the same way, the MTT assay could be correlated with cancer therapy in such a way that the MTT assay specifies the interaction of test compounds with cancer cells. In this assay, the viable cells and cells going through cytotoxicity are sorted out. The test compound has also been proved to be safe for the normal cell line to a considerable extent as it revealed the negligible cytotoxicity against WI-38. Moreover, the compound has also been proven to significantly inhibit $\alpha$-glucosidase. The $\alpha$-glucosidase is actually a carbohydrase which is involved in the breakdown of carbohydrates into glucose units. So, by inhibiting this enzyme, the carbohydrates will no longer be available in the smallest units to be absorbed from the gastrointestinal tract and this will ultimately decrease the concentration of glucose in the blood. The test compound in the current investigations has revealed a very significant anthelmintic potential by killing the test worm in a very short time. The test worms employed were $P$. posthuma which is known as earthworm and $A$. galli which is the worm of fowls. P. posthuma and A. galli have close physiological and anatomical resemblance with $A$. lumbricoides. That is why these worms have been exploited in the anthelmintic screening of our sample.

\section{Conclusions}

Based on the background data and current investigations of succinimide derivative, it may be deduced that 2-(2,5-dioxo1-phenylpyrrolidin-3-yl)butanal is a potentially bioactive compound and could be an important drug candidate against cancer, worms, diabetes mellitus and Alzheimer's disease, after going through further screening and evaluations.

\section{Acknowledgments}

We are grateful to Department of Pharmacy, University of Malakand, Chakdara, Khyber Pakhtunkhwa, Pakistan for provision of facilities to complete this project. The authors also extend their appreciation to Researchers Supporting Project Number (RSP-2019/110), King Saud University Riyadh Saudi Arabia for funding support. 


\section{Disclosure}

The authors report no conflicts of interest in this work.

\section{References}

1. Singh J, Sloan JA, Johanson NA. Challenges with health-related quality of life assessment in arthroplasty patients: problems and solutions. J Am Acad Orthop Surg. 2010;18(2):72. doi:10.5435/ 00124635-201002000-00002

2. Farooq U, Naz S, Shams A, et al. Isolation of dihydrobenzofuran derivatives from ethnomedicinal species Polygonum barbatum as anticancer compounds. Biol Res. 2019;52:1. doi:10.1186/s40659018-0209-0

3. Ullah I, Subhan F, Alam J, et al. Suppression of cisplatin-induced vomiting by cannabis sativa in pigeons: neurochemical evidences. Front Pharmacol. 2018;9:231. doi:10.3389/fphar.2018.00231

4. Ayaz M, Junaid M, Ullah F, et al. Molecularly characterized solvent extracts and saponins from Polygonum hydropiper L. show high antiangiogenic, anti-tumor, brine shrimp, and fibroblast NIH/3T3 cell line cytotoxicity. Front Pharmacol. 2016;7:74. doi:10.3389/fphar.2016.00074

5. Ayaz M, Sadiq A, Junaid M, et al. Neuroprotective and anti-aging potentials of essential oils from aromatic and medicinal plants. Front Aging Neurosci. 2017;9:168. doi:10.3389/fnagi.2017.00168

6. Ahmad S, Iftikhar F, Ullah F, et al. Rational design and synthesis of dihydropyrimidine based dual binding site acetylcholinesterase inhibitors. Bioorg Chem. 2016;69:91-101. doi:10.1016/j.bioorg.2016.10.002

7. Ayaz M, Junaid M, Ullah F, et al. Anti-Alzheimer's studies on $\beta$ sitosterol isolated from Polygonum hydropiper L. Front Pharmacol. 2017;8:697. doi:10.3389/fphar.2017.00697

8. Ayaz M, Junaid M, Ullah F, et al. Comparative chemical profiling, cholinesterase inhibitions and anti-radicals properties of essential oils from polygonum hydropiper L: a preliminary anti-alzheimer's study. Lipids Health Dis. 2015;14(1):141. doi:10.1186/s12944-015-0145-8

9. Ovais M, Zia N, Ahmad I, et al. Phyto-Therapeutic and nanomedicinal approach to cure alzheimer disease: present status and future opportunities. Front Aging Neurosci. 2018;10:284. doi:10.3389/ fnagi.2018.00284

10. Myint H. The Economics of The Developing Countries. Hutchinson Univ. Library; 1973.

11. Ayaz M, Junaid M, Ahmed J, et al. Phenolic contents, antioxidant and anticholinesterase potentials of crude extract, subsequent fractions and crude saponins from Polygonum hydropiper L. BMC Complement Altern Med. 2014;14(1):145. doi:10.1186/1472-6882-14-145

12. Ayaz M, Sadiq A, Wadood A, et al. Cytotoxicity and molecular docking studies on phytosterols isolated from polygonum hydropiper L. Steroids. 2019;141(p):30-35. doi:10.1016/j.steroids.2018.11.005

13. Kumar C, Anand Kumar H, Sunita V, Kapur I Prevalence of anemia and worm infestation in school going girls at Gulbarga, Karnataka. Indian Pediatr. 2003;40(01):70-72.

14. Ayaz M, Junaid M, Subhan F, et al. Heavy metalent fractions and crude saponins from polygonum hydropiper L. BMC Complement Altern Med. 2014;14(1):465. doi:10.1186/1472-6882-14-465

15. Ayaz M, Junaid M, Ullah F, et al. Chemical profiling, antimicrobial and insecticidal evaluations of polygonum hydropiper L. BMC Complement Altern Med. 2016;16(1):502. doi:10.1186/s12906-016-1491-4

16. Mohapatra S, Mohapatra P, Singh IJ, et al. Epidemiology of gastrointestinal and respiratory tract diseases in rural areas of Varanasi (India). Eur J Epidemiol. 1989;5(1):117-122. doi:10.1007/BF00145058

17. Valko M, Rhodes CJ, Moncol J, et al. Free radicals, metals and antioxidants in oxidative stress-induced cancer. Chem Biol Interact. 2006;160(1):1-40. doi:10.1016/j.cbi.2005.12.009

18. Shah S, Ahmad Z, Yaseen M, et al. Phytochemicals, in vitro antioxidant, total phenolic contents and phytotoxic activity of Cornus macrophylla Wall bark collected from the North-West of Pakistan. Pak J Pharm Sci. 2015;28:23-28.
19. Ahmad S, Ullah F, Sadiq A, et al. Chemical composition, antioxidant and anticholinesterase potentials of essential oil of Rumex hastatus D. Don collected from the North West of Pakistan. BMC Complement Altern Med. 2016;16(1):29. doi:10.1186/s12906-016-0998-z

20. Sadiq A, Zeb A, Ullah F, et al. Chemical characterization, analgesic, antioxidant, and anticholinesterase potentials of essential oils from Isodon rugosus Wall. ex. Benth. Front Pharmacol. 2018;9.

21. Powers AC, D'Alessio D. Endocrine pancreas and pharmacotherapy of diabetes mellitus and hypoglycemia. In: Brunton LL, Chabner BA, Knollmann BC, editors. Goodman \& Gilman's the Pharmacological Basis of Therapeutics. 12th. McGraw-Hill Education, New York; 2002:1237-1306.

22. Ovais M, Ayaz M, Khalil AT, et al. HPLC-DAD finger printing, antioxidant, cholinesterase, and $\alpha$-glucosidase inhibitory potentials of a novel plant Olax nana. BMC Complement Altern Med. 2018;18 (1):1. doi:10.1186/s12906-017-2057-9

23. Nugent TC, Negru DE, El-Shazly M, et al. Sequential reductive amination-Hydrogenolysis: a one-pot synthesis of challenging chiral primary amines. Adv Synth Catal. 2011;53:2085-2092. doi:10.1002/ adsc.v353.11/12

24. Ahmad G, Rasool N, Rizwan K, et al. Synthesis, in-vitro cholinesterase inhibition, in-vivo anticonvulsant activity and in-silico exploration of N-(4-methylpyridin-2-yl) thiophene-2-carboxamide analogs. Bioorg Chem. 2019;92:103216. doi:10.1016/j. bioorg.2019.103216

25. Iftikhar F, Yaqoob F, Tabassum N, et al. Design, synthesis, in-vitro thymidine phosphorylase inhibition, in-vivo antiangiogenic and insilico studies of C-6 substituted dihydropyrimidines. Bioorg Chem. 2018;80:99-111. doi:10.1016/j.bioorg.2018.05.026

26. Sarfraz M, Sultana N, Rashid U, et al. Synthesis, biological evaluation and docking studies of 2, 3-dihydroquinazolin-4 $(1 \mathrm{H})$-one derivatives as inhibitors of cholinesterases. Bioorg Chem. 2017;70:237244. doi:10.1016/j.bioorg.2017.01.004

27. Sadiq A, Mahmood F, Ullah F, et al. Synthesis, anticholinesterase and antioxidant potentials of ketoesters derivatives of succinimides: a possible role in the management of alzheimer's. Chem Cent J. 2015;9(1):31. doi:10.1186/s13065-015-0107-2

28. Mahmood F, Jan MS, Ahmad S, et al. Ethyl 3-oxo-2-(2, 5-dioxopyrrolidin-3-yl) butanoate derivatives: anthelmintic and cytotoxic potentials, antimicrobial, and docking studies. Front Chem. 2017;5:119. doi:10.3389/fchem.2017.00119

29. Nugent TC, Sadiq A, Bibi A, et al. Noncovalent bifunctional organocatalysts: powerful tools for contiguous quaternary-tertiary stereogenic carbon formation, scope, and origin of enantioselectivity. Chem A Eur J. 2012;18(13):4088-4098. doi:10.1002/chem.v18.13

30. Nugent TC, Bibi A, Sadiq A, et al. Chiral picolylamines for Michael and aldol reactions: probing substrate boundaries. Org Biomol Chem. 2012;10(46):9287-9294. doi:10.1039/c2ob26382c

31. Jabeen M, Choudhry MI, Miana GA, et al. Synthesis, pharmacological evaluation and docking studies of progesterone and testosterone derivatives as anticancer agents. Steroids. 2018;136:22-31. doi:10.1016/j.steroids.2018.05.008

32. Kumkrai P, Weeranantanapan O, Chudapongse N. Antioxidant, alpha-glucosidase inhibitory activity and sub-chronic toxicity of derris reticulata extract: its antidiabetic potential. BMC Complement Altern Med. 2015;15:35. doi:10.1186/s12906-015-0552-4

33. Rahim H, Sadiq A, Khan S, et al. Fabrication and characterization of glimepiride nanosuspension by ultrasonication-assisted precipitation for improvement of oral bioavailability and in vitro $\alpha$-glucosidase inhibition. I J Nanomedicine. 2019;14:6287-6296. doi:10.2147/IJN. S210548

34. Jabeen M, Ahmad S, Shahid K, et al. Ursolic acid hydrazide based organometallic complexes: synthesis, characterization, antibacterial, antioxidant, and docking studies. Front Chem. 2018;6:55. doi: $10.3389 /$ fchem. 2018.00055 
35. Ahmad S, Ullah F, Ayaz M, et al. Antioxidant and anticholinesterase investigations of Rumex hastatus D. Don: potential effectiveness in oxidative stress and neurological disorders. Biol Res. 2015;48(1):20. doi:10.1186/s40659-015-0010-2

36. Hussain F, Khan Z, Jan MS, et al. Synthesis, in-vitro $\alpha$-glucosidase inhibition, antioxidant, in-vivo antidiabetic and molecular docking studies of pyrrolidine-2, 5-dione and thiazolidine-2, 4-dione derivatives. Bioorg Chem. 2019;91:103128. doi:10.1016/j.bioorg.2019.103128

37. Zeb A, Sadiq A, Ullah F, et al. Investigations of anticholinestrase and antioxidant potentials of methanolic extract, subsequent fractions, crude saponins and flavonoids isolated from Isodon rugosus. Biol Res. 2014;47(1):76. doi:10.1186/0717-6287-47-76

38. Zeb A, Ullah F, Ayaz M, et al. Demonstration of biological activities of extracts from Isodon rugosus Wall. Ex Benth: Separation and identification of bioactive phytoconstituents by GC-MS analysis in the ethyl acetate extract. BMC Complement Altern Med. 2017;17:284. doi:10.1186/s12906-017-1798-9
39. Ullah F, Ayaz M, Sadiq A, et al. Phenolic, flavonoid contents, anticholinesterase and antioxidant evaluation of Iris germanica var; florentina. Nat Prod Res. 2016;30(12):1440-1444. doi:10.1080/ 14786419.2015.1057585

40. Zohra T, Ovais M, Khalil AT, et al. Bio-guided profiling and HPLCDAD finger printing of Atriplex lasiantha Boiss. BMC Complement Altern Med. 2019;19:4. doi:10.1186/s12906-018-2416-1

41. Mir NT, Saleem U, Anwar F, et al. Lawsonia Inermis markedly improves cognitive functions in animal models and modulate oxidative stress markers in the brain. Medicina. 2019;55(5):192. doi:10.3390/medicina55050192

\section{Publish your work in this journal}

Drug Design, Development and Therapy is an international, peerreviewed open-access journal that spans the spectrum of drug design and development through to clinical applications. Clinical outcomes, patient safety, and programs for the development and effective, safe, and sustained use of medicines are a feature of the journal, which has also been accepted for indexing on PubMed Central. The manuscript management system is completely online and includes a very quick and fair peer-review system, which is all easy to use. Visit http://www. dovepress.com/testimonials.php to read real quotes from published authors. 